\title{
Reaction of scrap-free alloy in water
}

\section{スクラップフリー合金の水との反応性}

\author{
Hiroyuki IZUMI, Tetsuo AIDA, Junichi KAWANO, Mineki OGATA \\ and Yoshitake NISHI.
}

Department of Materials Science, Tokai University, 1117 Kitakaname, Hiratsuka, Kanagawa, 259-12 JAPAN. TEL :81-463-58-1211 ext.4206 Fax :81-463-58-1812 ( Accepted for publication 16 November 1995 )

\begin{abstract}
When the Mg-Li alloy reacts water, it generates the electromotive force, reaction heat and $\mathrm{H}_{2}$ gas. The lithium addition decreases electromotive force and increases the generated volume of hydrogen. These properties are useful to generate the electric power.
\end{abstract}

KEY WORDS Mg-Li alloy, Electromotive force, Ecological alloys

\section{INTRODUCTION}

Mg は大量に使井されている材料の中では最 も軽量である事が特徵である。 $\mathrm{Mg}$ にさらに軽 量な元秦である Li を添玑しから夜体急冷法に より作製することにより、一層軽量（比重 1 以

ト）で比強度の優れた材料が得られる可能性が ある。1.2またこの材料は水と反念して溶解・消 失しスクラップが出ない合金である。しかも间 時に水素を発生し、さらに電極として利用示れ ば電池として利朋できる问能性がある。このエ コロジカルマテリアル Mg-Li 合金の水との反 念性仗び、暼力源としての利用の可能性につい て研究を行った。

\section{II . EXPERIMENTAL}

試料の作製には高純度の $\mathrm{Mg}(3 \mathrm{~N})$ おうよび $\mathrm{Li}$ (2N) を原料として用いた。 Mg 及び Li を任意 の比弦となるよう秚量し、双ピストンアンビル 型急冷凝固装置を用いて液体急冷を行つた。 Fig.1 に装置図を示す。試料は石英管中、Ar$5 \% \mathrm{H}_{2}$ 霑䎴父帆で溶解した。

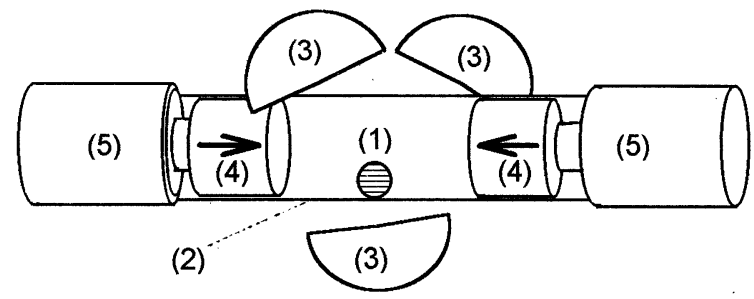

(1) Specimen

(4) $\mathrm{Cu}$ substrate

(2) Quartz tube

(5) Air piston

(3) Infrared furnace

FIG. 1.Twin type piston anvil apparatus.

この装置は融点直下から急冷凝固できる為、 一般の他の急冷装置に比バ組成が変化しないこ とが特徴である。

$\mathrm{Mg}-\mathrm{Li}$ 合金が水中に溶解するときに生ずる 起電性は刘杫に䈐素棒を使用し測定した。試料 と蒸留水との反态ガスは Fig.2 に示す様に試 料を水中に挿入して収集した。蒸留水の温度は 293K 一定とした。 


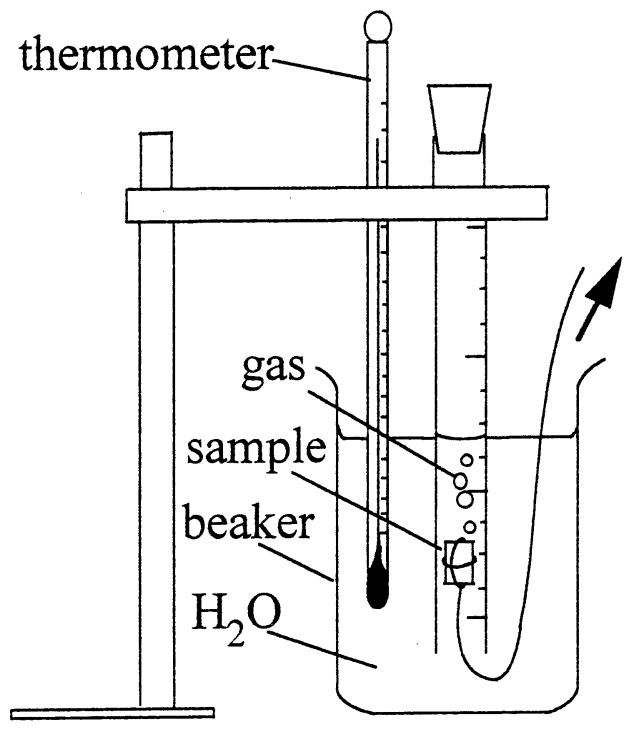

FIG.2. Schematic diagram for collecting reaction gas between $\mathrm{H}_{2} \mathrm{O}$ and $\mathrm{Mg}-\mathrm{Li}$ alloy.

\section{RESULT}

Figure3に Li 会有量による起電压の変化を示 与。最大の起電忙は Mg-50 at \% て見られ、Li 含有星の増大と共に起電王は減少 した。

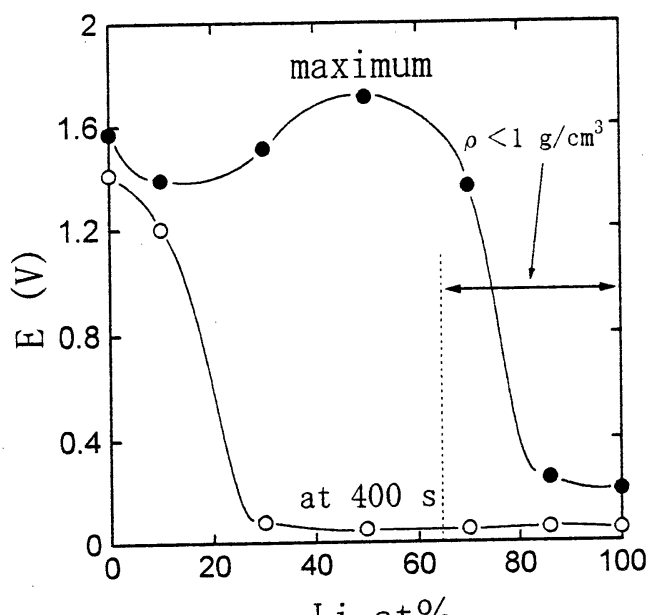

FIG.3. Changes in electromotive force $\mathrm{E}$ versus lithium concentration.

Figure3にLi 会有輻による水素発生量の変化 を亦す。水素ガスの発生は次式により亦される。

$$
\mathrm{Li}+\mathrm{H}_{2} \mathrm{O} \rightarrow \mathrm{Li}^{+}+\mathrm{OH}^{-}+1 / 2 \mathrm{H}_{2} \uparrow
$$

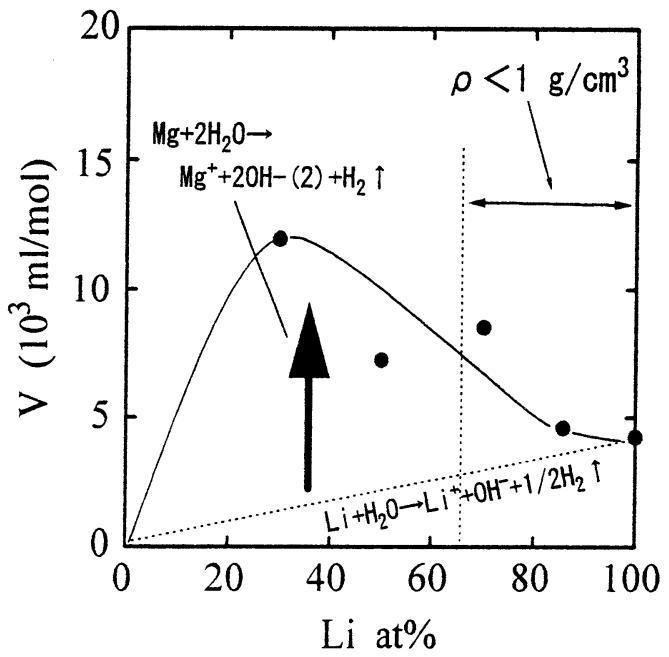

FIG.4. Changes in volume of hydrogen $\mathrm{V}$ versus lithium concentration.

Li と水の攵志は熱を生ずる。もしこの熱によ り $\mathrm{Mg}$ と水の反志が引き起こされるとすると、 闹様に水素ガスが次式により生ずる。

$\mathrm{Mg}+2 \mathrm{H}_{2} \mathrm{O} \rightarrow \mathrm{Mg}^{+}+2 \mathrm{OH}^{-}+\mathrm{H}_{2} \uparrow$

Figure4において Li の夕が水と父忍したとき の理論值に対して実测值は Li 30 at \%におい て最も大きく、Li 含有量が 30 at \% 以ドでは急 速に減少する。この差は常温では水とほとんど 反态しない $\mathrm{Mg}$ が $\mathrm{Li}$ の反圭熱により水と反応 し、 $\mathrm{H}_{2}$ を発生した為である。Li 30 at\%以下゙で は $\mathrm{Li}$ と水の閐の父熱が小さく Mg の文心が 起きにくかった為水素発生量が少ないといえる。

$\mathrm{Mg}-\mathrm{Li}$ 合金は水素を発生しながら水に溶 解・消失しスクラッブが出ないエコロジカルマ テリアルである。また電極として利用すること によって電う源としての利用の可能性があると いえる。

\section{REFERENCES}

${ }^{1}$ Y.Kojima and S. Kamado, Kinzoku, 6,4 (1994).

${ }^{2}$ Y.Nishi, M. Tachi and E. Yajima. Scr. Mctall, 19,289 (1985).

${ }^{3}$ Y.Nishi, K. Suzuki and T. Masumoto, J. Jpn. Inst. Metals, 45,181 (1982).

'95 SAS Intelligent Symposium 